\title{
Engineering Education in India: Preparation of Professional Engineering Educators
}

\author{
Atasi Mohanty, Deepshikha Dash \\ Centre for Educational Technology, Indian Institute of Technology, Kharagpur, India \\ Email: atasi_mohanty@yahoo.in, atasim@cet.iitkgp.ernet.in \\ Received 11 April 2016; accepted 14 June 2016; published 17 June 2016 \\ Copyright (C) 2016 by authors and Scientific Research Publishing Inc. \\ This work is licensed under the Creative Commons Attribution International License (CC BY). \\ http://creativecommons.org/licenses/by/4.0/ \\ (c) (i) Open Access
}

\begin{abstract}
In 21st century, engineering education in India faces significant challenges as it requires meeting the demands of technical profession and emerging job market. Researchers have found some universally preferred, yet challenging skills for global workforce, e.g., science, technology, engineering and math (STEM), statistics and data analysis skills, are of the topmost priority. Moreover, after being the signatory of Washington Accord, India needs to reinvent not only the India Inc., but also its technical/engineering education system. Recently, we have witnessed a major shift in customer relationship and business strategies of corporate houses. Nowadays, e-learners and online consumers are increasing, for which we have to update our digital world, i.e., infrastructure, content/domain knowledge, educators/HR trainers. Thus, our technical faculty should need to learn the innovative approaches to teaching and learning, which in turn will require effective professional development for both new and experienced instructors alike. It is high time now to redesign our curricula, pedagogy and make the pre-service teacher preparation programme mandatory part of technical higher education.
\end{abstract}

\section{Keywords}

Technical Education, Professional Development, Pre-Service Teacher Preparation, Curriculum, and Pedagogy

\section{Introduction}

In this 21st century globalized world, the engineering education and the profession are facing various challenges and at the cross-road, the developed countries see it as an opportunity for positioning themselves as knowledge super-powers, whereas the developing countries like India and other Asian countries are striving towards knowledge capital, know-how, skilled-manpower, infrastructure and ecosystem for big investments for business and 
entrepreneurship. In this context, the education of engineers of any country is very critical/crucial for determining its global positioning as well as ensuring the prosperity of their citizens. In this digital world, knowledge is no longer confined to experts only, rather computer and internet connectivity has empowered every citizen to look for anything and everything.

Thus, the education pattern, nature of jobs and services are fast changing across the world. Skill is rapidly becoming a commodity that can be bought from low-cost providers anywhere across the globe. It doesn't matter how much you know or how to do these; someone else knows it too and is willing of various services from developing countries with cheap labor/cost. Hence, the solution to this will be to make "innovation" the central theme of educational and social developmental programmes.

Higher Education in general and engineering education in particular requires a total transformation in order to meet the needs of employers and challenges being faced by professional communities, while working in the multidisciplinary and diversified work set-ups. Moreover, various review reports have pointed out that there exists a misalignment between engineering education and practice; engineering educators hardly understand engineering practice beyond design and technical problem solving; this large gap between education and practice has become traumatic for young engineers, forcing them to think about alternative occupations [1]. The UNESCO report [2] has also pointed out some critical issues.

1. Employers are not happy with the capabilities of engineering graduates and post-graduates.

2. Engineering education seems to be boring to many students.

3. Engineering education has failed to attract the talented students who really want to contribute for social development.

4. Engineering programmes are reputed to be difficult, thus mostly avoided by the students.

5. Engineering requires multidisciplinary knowledge, work experience.

6. Various application oriented skills and innovative approach have not been addressed by engineering curriculum.

7. Even though many desirable attributes of engineering graduates have been described in Washington Accord (WA), hardly these are being addressed by engineering educational institutions.

8. Project Based Learning (PBL) or Project Centered Learning (PCL) is a valid/proven approach, which can be incorporated in any semester in engineering degrees.

9. Students' (learning) engagements and pedagogy can be made more effective through proper use of ICT and inquiry-based learning.

10. Many web-based engineering course materials and open-source learning materials can be better used/utilized for enhancing engineering teaching-learning process.

11. Engineering accrediting authorities must play the key role (i.e., Washington Accord, ABET signatories) in mobilizing the engineering educational institutions to modify their programmes, their relationships with students, role of academic staff/educators, infrastructure facilities, networking with employers, as well as assessment and evaluation methods, to improvement and evaluation methods, to improve the effectiveness of these programmes.

\section{Empirical Research on Professional Development of Engineering Educators/Teachers}

Empirical research on "Teacher Education" has confirmed the positive correlation between effective professional development and improved teacher practice, which has in turn been linked to improved student performance [3]. The current emphasis of professional teacher preparation programmes in major subjects like Science, Technology, Engineering and Mathematics (STEM) and the interrelationships, which require new strategies and efforts to understand and explain the nature of professional development for teachers of engineering, both as a unique discipline and as a context for teaching and learning in other subjects [4]. One of the most frequently cited aspects of effective professional development in the literature is the quality improvement of teachers' content knowledge [5]; which indicates a positive correlation between content focus in professional development and increased teacher knowledge; improved pedagogy and moderate enhancements in students' achievements [6] [7]. Research indicates that practicing strategies for success in engineering (e.g., design requirements like collaboration and teamwork, asking questions, communication about ideas and design specifics, careful documentation) is highly effective in developing teachers' content knowledge [8]-[11]. There is an urgent need and importance of engaging professional teachers in complex thought instead of simply presenting them with information 
in order to challenge pedagogical knowledge and confront teachers with a transformative cognitive dissonance [12]. Thus, deepening pedagogical content knowledge for professional engineering educators has been advocated by many researchers, as it would provide opportunities to teachers/educators/participants to experience and explore the ways in which the engineering design process can be used to teach both engineering specific concepts and concepts common to multiple STEM disciplines [12]-[14]. Moreover, the professional development of engineering teachers should support the evolution of their pedagogical skills by building a learning community and make it clear how engineering design and problem solving offer a context for teaching standards of learning Science, Mathematics, Language, Arts and all across other subjects [10] [15]-[19].

The professional teacher preparation programme should also empower the teachers to identify appropriate curriculum, instructional materials and assessment methods. In support of this researchers have claimed that "to establish a firm foundation for improved student outcomes, teachers must integrate their knowledge about curriculum, and about how to teach it effectively and how to assess whether students have learned it” [20]. Furthermore, this should be aligned to current educational research and student learning standards. In the present context engineering education should be more than just a transfer of knowledge; all the 21st century skills mentioned in "Washington Accord", "ABET" or other Accreditation Bodies/Authorities, such as creativity and innovation, communication, critical thinking, interpersonal skills, collaboration and team-work should also be equally incorporated in the curriculum and pedagogy [4] [21].

Thus, professional development programmes for engineering educators must be flexible enough to meet the needs of teachers, students, employers, as well as academic authorities/governing bodies. Engineering teacher preparation programmes/pre-service professional development programmes should be designed and imparted in such a way that teachers would be encouraged to ask themselves that which concepts can be learned through a specific activity, what students are actually learning and which aspects of the activity are most effective in this learning, how a lesson might be changed to improve its transfer to a real/virtual classroom and whether there might be opportunities to connect and reinforce learning from other content areas [18]. Hence, it has been suggested that effective professional development program design must possess the following characteristics:

a. It should be reform-oriented such as grounded in inquiry, reflection, problem solving, and experimentation.

b. Must engage students, teachers, parents, employers, educational authorities as well as a wider community through collective and collaborative participation.

c. Should involve the participants in active, in-depth learning activities.

d. Should also be based on a well-defined image of effective classroom learning and teaching.

e. Focus should be both on content and pedagogy and embedded on global culture context.

f. Should have the mechanism of continuous improvement, evaluation and follow-up.

\section{Indian Engineering/Professional Education Scenario}

The establishment of the Indian Institutes of Technology, Indian Institutes of Management and Indian Institutes of Science were a crucial decision in the development of technical education in the Indian scenario. These institutions aim to produce competent and hard core intelligent engineers and scientist that would change the outlook of India on the global prospect. India was earlier known for yoga, meditation and holy places, but now it is renowned for computer engineers. Here in India, technical education starts from craftsman level and extends up to post doctoral level. Role of each level has its own significance.

\subsection{Brief History of Technical Education in India}

The commencement of formal Technical Education in India started in the period of mid of 19th century. The first school was opened in Chennai in 1794. Later on, technical education expanded to other parts of the country. The engineering colleges were established in different segments of India. These are as follows: Chennai in south (1794), Roorkee in north (1847), Pune in west (1854) and Kolkata in east (1856) for providing education and training for the engineers in the country. An engineering college was started in BHU campus from 1919. All of these reputed technical institutions still exist today. An important step with far reaching consequences taken in the pre-independence period was the constitution of the Sarkar Committee (33) in 1945. It recommended the setting up of at least four higher technical institutions on lines with the Massachusetts Institute of Technology (MIT) USA, spanning the length and breadth of India. 


\subsection{Post-Independence Era: Growth of Engineering Education in India}

At the time of independence in 1947, the number of engineering colleges and polytechnics were 44 and 43 respectively with an annual intake capacity of 3200 and 3400 respectively [22].

i. Indian Institutes of Technology (IITs): Acting upon the recommendations made by the Sarkar Committee, five IITs were established at Kharagpur (1951), Bombay(1958), Madras (1959), Kanpur (1960) and Delhi (1961) by acts of Parliament (Kakodkar Committee Report, 2011). Later on, sixth IIT was established in Guwahati (1994) to meet the regional aspirations. India's premier technical institute, set up in 1847 in Roorkee and known as the Thomson College of Engineering and subsequently the University of Roorkee, was made the seventh IIT in 2001. Six new IITs were started in Bhubaneswar, Gandhinagar, Hyderabad, Patna, Jodhpur and Roper in 2008 followed by two more in Indore and Mandi in the year 2009. The Institute of Technology at BHU was granted the coveted status of IIT in 2012 and was renamed as IIT (BHU). Recently the Indian Government in its Union budget for the financial year 2014-15 announced the proposal to set up five more IITs in the states of Jammu, Chhattisgarh, Goa, Andhra Pradesh and Kerala.

ii. National Institutes of Technology (NITs): In the next tier institutions, there are 30 NITs with liberal funding from Central Government and autonomous structure much similar to IITs. The NITs were declared INI in 2007. These were established in the backdrop of Second Five Year Plan (1956-61) to ensure the supply of trained manpower for the industrial projects undertaken during the plan. In the first phase, eight Regional Engineering Colleges (RECs) were set up. All RECs were later renamed and restructured as NITs in 2002.

\subsection{Expansion and Privatization of Engineering Education}

In the early 1980s, there were about one hundred engineering colleges admitting around 25,000 students each year. Government institutions became insufficient to cater to the demands of the industry during successive Five Year Plans and particularly with the implementation of the policy of liberalization and globalization. This led to force the Government to allow and facilitate the private to set up technical institutions on self-financing basis. Hence, there has been mushrooming of engineering institutions and it started with the opening up of about 50 new private engineering colleges in Tamil Nadu over a small period of time. This mushroom growth was opposed by the academic community at that time, as they thought this would decrease the standard of engineering education. Today, India produces 1.5 million engineering students from around 3500 engineering institutions annually. The quality of education in these private colleges is very unbalanced. Many of these colleges lack even basic facilities essential for good engineering education and have practically no quality teachers at all. But on the other hand, some have excelled and are as good as or even better than many of the Government engineering colleges today. In spite of the varying standards, India has been benefitted immensely from this growth. This is evident from the glorious heights the Indian industry has touched in the past decades. Deemed Universities have also mushroomed. Most of them do not belong to the same class as those recognized as such twenty years ago. This provision was reserved for a few truly outstanding education and research institutions, with a consideration that they would bring depth and variety into the education system.

\subsection{Process Outcomes: Advantages \& Opportunities}

India acquires many important advantages which hasten extensive opportunities and play a vital role in the developing global knowledge economy. Some of the advantages and opportunities in this regard are [23]:

i. Erudition and knowledge generation and circulation is the tradition of India from ancient times. For example, "Ayurveda", is not fully documented or systematized or made up-to-date.

ii. In the first decade or so after independence, five IITs were set up, which provided world-class engineers at the undergraduate level. These world-class graduates made brilliant image. Leading and excellent institutions in India can attract and enroll international students, which would bring about the much needed student interactions and financial inputs.

iii. By providing a well-trained, innovative workforce not only to India, but possibly to other countries as well we can bring rapid progress in quality technical education.

iv. English is the language of global knowledge economy. India is fortunate to have the largest number of English-speaking people, perhaps next to the US.

v. India has a fairly command on information, communication and technology (ICT) network, which is im- 
proving by time to time. Hence good quality education can be accessed by people even in rural areas.

vi. The middle income population in India is growing rapidly. This leads to demand for quality education. More people recognize the importance of quality education in life and have the resources and willingness to spend on good education.

\subsection{Setbacks \& Challenges}

There is no doubt that quantitative growth of engineering education in India has increased the opportunities for engineering aspirants and has contributed to nation's growth. But the maintenance of quality has become the victim of this growth phenomenon. Lack of maintenance of standards in institutions and failure to monitor the same by the regulating bodies is the main factor responsible for this scenario in the country.

Undergraduate Engineering Education: Self-financing private engineering colleges are providing more than $85 \%$ of the engineering graduates in the country. According to the National Association of Software and Services Companies (NASSCOM), less than $25 \%$ of the graduate engineers are employable. It seems appropriate guidelines and corrective measures are not followed while granting sanctions to new colleges and disciplines. Main motive of the most private colleges is only profit making rather than providing quality education. Even many Government institutions are found lacking in quality education due to political interference resulting in poor governance. Many factors lead to poor quality of education. Some of these are [24]:

- Shortage of quality faculty.

- Inadequate physical infrastructure and funds.

- Lack of autonomy.

- Rigid and outdated curriculum.

- Poor quality of training.

- Absence of R \& D activities.

- Poor learner quality.

- Ineffective linkage with industry.

The shortage of quality faculty is the most serious problem confronting Indian engineering education system.

\subsection{Current Needs}

1. The students of engineering colleges of each state of this country should be given apprenticeship, and on-the-job training opportunities and this will widen the availability of trained human resources to the industries of the region. Further, it will also expand the placement opportunities of the students in the industries and service sector. It would also enhance the research potential of the industries. All the inventions and innovations stem out from the developed nations, are the result of tremendous effort that they put in R \& D. Thus R \& D facilities have to be promoted in the industries [25].

2. Globalization has compelled industries to produce standardized, calibrated and quality products; here institutes can help industries of the region in providing easy access to this.

3. Institutions have to become more responsive to changing labor markets and students' interests. Unfortunately, universities are not particularly innovative institutions; they are not well suited to quickly pulling together whatever resources are needed to respond to a new problem / challenge. This problem is more serious in India due to the structural rigidities of the system, near absence of competition between institutions, and mindset of the stakeholders.

4. In recent years, survival initiatives have been taken to bridge the gap. Industry specific and context specific solutions are being tried in many sectors. Experience has shown that private institutions are far more adaptable and non-formal provision is better in responding to the students' demand. Thus, a suitable mix of the public and the private, the formal and the non formal provision for higher education and training provides an optimal solution and would meet the changing needs of economy and society.

5. Unified education and training system are best suited to respond to changes in the job markets. This would require building pathway between the vocational and the higher education sectors through a national qualifications framework and re-branding of vocational education. Managing "Public-Private Partnership" and devising policies that ensure healthy growth of both the public and the private sectors are needed.

6. The problem lies in the fact that our education system is designed for those who wish to pursue higher studies in universities or in technical institutions [medicine/engineering etc.] making no allowance for those who 
do not have the aptitude for higher studies. The result is that students either drop out after Class Ten/Twelve or enroll in degree colleges for want of anything better to do. We thus spend huge amount on producing a large number of unemployable youth who hold university degrees. They are not educated unemployed, but unemployable graduates! Any employer will tell you how frustrating it is to get the right people for available jobs. Construction companies do not get adequately trained masons, carpenters, blacksmiths, electricians, etc. Offices cannot get good stenographers, computer operators, accountants, etc. Factories and workshops cannot get mechanics and technicians. These graduates do not possess employable skills even if they are considered educated. Irrespective of what parameters are used to rank academic institutions, Harvard, MIT, Stanford, Oxford, Cambridge, etc. are among the top few, India does not appear even in the first 200. It is important for India to understand what it takes to achieve excellence and how to retain it decade after decade. Mashelkar [26] identified the following criteria:

$>$ Totally uncompromising supremacy of teaching and research.

$>$ From the Frontiers thrust not only on "working” repeatedly, but “creating” new frontiers. This implies "to lead" and not just "follow".

> A determined emphasis on selecting the very best for both in faculty and students on a universal scale. The same accuracy is viciously applicative for promotion, so that only the most talented and proficient faculty will be detained.

$>$ Everlasting commitment to true institutional liberty in all matters, with no political interference whatsoever.

$>$ Accreditation of Engineering Courses

National Board of Accreditation (NBA) is entrusted with the task of periodically evaluating technical institutions and programs based on the norms and standards laid down by the All India Council of Technical Education [22]. The motive of accreditation is to encourage excellence in technical institutions at the UG and PG levels. NBA was established in 1994 by AICTE. NBA changed its accreditation norms and procedure in 2009 to be in tune with international standards as per the Washington Accord which requires its member countries to exercise uniform norms in technical education at UG level. India finally became the 17th member of the Washington Accord recently on 13th June 2014 [27]. It will help create equivalence of engineering degree courses and allow Indians to practice engineering in other member countries. NBA has shortlisted 220 engineering colleges as tier-I institutes whose UG engineering programmes are in tune with what is required under the accord. Washington Accord will, however, not be valid for IT engineers. India will have to sign the Seoul Accord to create similar equivalence of programmes.

\section{Current Scenario \& Global Issues}

With knowledge-based economy in a globalization-governed world, engineering educational institutions own the responsibility of producing qualified and competent graduates who are expected to be the multi-tasking professionals who should be equipped with a long list of hard (technical) as well as soft (professional) skills. Nowa-days, an engineer is a skilled applicator of science equipped with mathematical and technical knowledge, well versed with technological tools and ready to take up any problem in this competitive world. Moreover, the integration of technology into our everyday lives and its presence in every little corner of this world has made it literally mandatory for the 21st century engineers to be entrepreneurial, able to gather information and decide the plan of actions, including the tools, techniques and experts in various fields. Thus, they are required to learn/ develop technical skills, management skills, problem-solving skills as well as the visionary leadership skills. They have to meet the criteria like:

I. Must know how to transform information into knowledge by quickly evaluating its efficacy and authenticity.

II. Should be able to quickly assess what needs to be done, can acquire tools needed and use these proficiently.

III. Can work with anybody anywhere, has the communication and networking skills, team skills, and understanding of global and current issues necessary to work efficiently and effectively with other people. In essence to build the competencies of know-what, know-why, know-how and know-who.

IV. Who would be able to imagine and materialize these into a reality, has the entrepreneurial spirit, managerial skills to identify needs and come up with new solutions to our day-to-day problems.

A detailed survey of novice engineers' work schedules reveal that the fresher spend $60 \%$ of their office/work time explicitly integrating with other people [28], of which about $32 \%$ is verbal (face to face or telephone calls), and the remaining $28 \%$ in writing [29]. Thus, the young engineers are most likely to spend more time in listen- 
ing during the initial training/probation period than learning speaking oral and written communication. It also implies that while engineering practice is dominated by informal listening and speaking, these communication skills are seldom even mentioned in engineering courses [30]. Moreover, we can better understand engineering practice by reframing engineering as human social performance [31]. We can only fully understand engineering if we understand how people think, feel, and respond, interact as they perform their task in the workplace. Like most human performance, engineering performance is also time, information and resource constrained. The engineering professionals have to allocate time and attention/effort to satisfy diverse needs and demands embed in their jobs. They have to play multiple roles. For example, they need to ensure that everyone involved in producing products or providing utility services has sufficient understanding of the essential features that will add value to ensure that these are being properly implemented through planning, detailed design, production, delivery, operations and maintenance. The stakeholders who use the products and services need to make effective use of them for gaining total value.

Therefore, to be a global player, the production of knowledge cannot be expected to be done within the walls of educational institutions alone but within the context of joint platform and shared responsibilities of both "Academia" and "Industry". As learning by doing is essential the partnership between industry and academia becomes an urgent need for grooming our young engineering graduates. Moreover, our engineering educators will need to be trained in different contents and instrumental methods in order to meet the challenges of globalization [32]. It's high time now for India to seriously think, discuss and develop internationalized programs of engineering teacher education in order to cope with the demand and necessity of qualified professional teachers/ educators to groom our professional graduate in order to implement the "make in India", and "skilled/manpower" or "digital India" policy concepts. With the explosion of knowledge and technology engineering educators must rethink how students are prepared in the foundation subjects of their discipline. Today, computer programs virtually do everything, from conducting simple calculation to simulating complex systems to design a complete engineered artifact, empower the modern engineer to do more than his or her predecessors could ever imagine. Hence, the common sense will be more important/required when the designs and analyses are done exclusively on computer. Therefore, while teaching engineering students, how the physical world works is the crux of technical education today, for which we need to re-examine, how we teach fundamentals of engineering science as well as professional skills. Most of the academic programs now require their graduates to exhibit proficiency in oral and written communication and to be able to work in diverse workplace. Preparing young engineers to work in a flat world require every student to develop the right knowledge, attitude and skills necessary to function globally and effectively. Thus, we need to examine the curriculum and pedagogy of professional engineering education as well as teacher preparation/pre-service teacher education programmes in engineering and other professional fields.

\section{Global Attributes \& Competencies to Be Developed through Professional Engineering Educators}

The report of "The Engineer of 2020: Visions of Engineering in the New Century" of U.S. National Academy of Engineering [33] stated that "technology has shifted the societal framework...with new developments in nanotechnology, logistics, biotechnology and high performance computing... The economy in which we will work will be strongly influenced by the global marketplace for engineering services, a growing need for interdisciplinary and system-based approaches, demands for customerization and an increasingly diverse talent pool"-The U.K. Royal Academy of Engineering [34] report states that "For educating 21st century engineers, both the academia and industry emphasized the university engineering courses need redesigning for the modern economy, more hands on experience on problem - solving, group projects and applying theory to solve real industrial problems as well”. Researchers have also promoted the notion of acquiring professional/soft skills besides hard/domain skills for today's engineers [35]-[37]. The global and competitive workplace requires an engineer to be able to work in a multicultural, multidisciplinary environment, hence, need to develop team skills and leadership skills [38] [39]. Recently, engineers have become more specialized in their work, education and the modern engineering curricula have not produced graduates with well-rounded skill sets [40], thus a good amount of coursework in humanities and social—sciences are recommended here, besides technical skills. Moreover, the importance of emotional intelligence in an engineer's success places pressure on engineering curricula to foster this among graduates in order to perform effectively as professionals. Many engineers find that their ca- 
reer paths automatically lead them to managerial and executive positions, requiring the ability to attain adequate business skills in order to sustain competitive advantage at professional/corporate level [41]. Hence, engineers must be able to connect the business world with the scientific community and innovation [42]. Therefore, a comprehensive framework of both the technical and non-technical skills is required to be well integrated into the 21st century engineering and technical teacher education programmes [43]. All the professional/accreditation bodies like ABET [44], Washington Accord [45] or NAB [46] have already elaborately stated about the students' learning outcomes, programme educational outcomes, list of competencies, professional/ethical responsibilities of engineers/engineering educators/academic institutions. In addition to this, to ensure the quality of our professional engineering and teacher education programmes we need to focus on continuous and authentic/valid improvement driven assessment process and life-long professional development programmes.

\section{Educational Implications}

Even though some reputed higher education institutes make substantial progress in preparing engineering students as industry — ready professional graduates, still we need to go a long way because of the global nature of engineering organizations, technology infiltration, multidisciplinary of the problems, diversity in worlds' cultures etc. Therefore, higher education system and accreditation agencies along with their constituent bodies must collaborate with industries and share the best practices, update their academic/research programmes and equip with contemporary latest technological tools, to be the active global players in the world market. The suggested steps could be as follows:

1. Offering different types of courses as breadth electives, thin specializations, micro-credit courses in various technical, skills related or interdisciplinary subjects to the students during 04 years B.Tech. or 05 years Dual degree (B.Tech. with P.G.) programmes.

2. Encourage and reward faculty members/engineering educators to carry out globally relevant research, which are compatible with the needs of a globalized world.

Incorporate student exchange programme as a part of internship/on-the-job work experience international academic experience.

3. Integration of latest technology, tools and new pedagogy of deep learning into the curriculum.

4. Partner with other universities (worldwide), centers of excellence, professional bodies, and global industries through sponsoring workshops, seminars, expert talks, visiting professorships, collaborative projects.

5. Establish global standards in relation to accreditation and quality assurance, introduce standardized evaluation system for measuring students' learning outcomes, and teachers professional competencies.

6. Adopt flexibility yet objectivity in introducing new courses, programmes, placement/career development workshops/hands-on experiences, strengthen the international (alumni) networks and be a part of international/ authentic/global ranking system by meeting the criteria.

\section{Conclusion}

There is a urgent need to address the problems ailing the technical education; otherwise India will miss the opportunity to utilize its demographic dividend of a young work force which it has. In order to ensure standards as per global norms and mechanism to monitor the same, uncompromising attitude is essential. In this respect, India becoming a permanent member of the Washington Accord is a significant step. Education in India needs to be more skill oriented-both in terms of life-skills as well as livelihood skills. In sheer numerical terms, India has the man power to substantially meet the needs of a world hungry for skilled workers, provided its education system can convert those numbers into a skilled work-force with the needed diversity of skills. Hence, we need to promote partnership between NGOs, private sector and public sector, along with increasing scope of apprenticeship training in service sector, informal sector and high tech sector.

\section{References}

[1] Edward, N.S. and Middleton, J.C.R. (2001) Occupational Socialization-A New Model of the Engineer's Formation. Paper Presented at the International Conference on Engineering Education, Oslo, 6-10 August 2001.

[2] Beanland, D. and Hadgraft, R. (2013) Engineering Education: Transformation and Innovation. UNESCO Report.

[3] Darling-Hammond, L., Wei, R.C., Andree, A., Richardson, N. and Orphanos, S. (2009) State of the Profession: Study Measures Status of Professional Development. Journal of Staff Development, 30, 42-44. 
[4] Reimers, J.E., Farmer, C.L. and Klein-Gardner, S.S. (2015) An Introduction to the Standards for Preparation and Professional Development for Teachers of Engineering. Journal of Pre-College Education Research, 5, 40-60.

[5] Guskey, T.R. (2003) What Makes Professional Development Effective? Phi Delta Kappan, 84, 748-750. http://dx.doi.org/10.1177/003172170308401007

[6] Blank, R.K., De Las Alas, N. and Smith, C. (2007) Analysis of the Quality of Professional Development Programs for Mathematics and Science Teachers: Findings from a Cross-State study. Council of Chief State School Officers, Washington DC.

[7] Garet, M.S., Porter, A.C. and Desimone, L.M. (2001) What Makes Professional Development Effective? Results from a National Sample of Teachers. American Educational Research Journal, 38, 915-945. http://dx.doi.org/10.3102/00028312038004915

[8] Custer, R.L. and Daughtery, J.L. (2009) Professional Development for Teachers of Engineering: Research and Related Activities. K-12 Engineering Education. The Bridge, 39, 18-24.

[9] Donna, J.D. (2012) A Model for Professional Development to Promote Engineering Design as an Integrative Pedagogy within STEM Education. Journal of Pre-college Engineering Education Research, 2, 2. http://dx.doi.org/10.5703/1288284314866

[10] English, L.D., Hudson, P. and Dawes, L. (2013) Engineering-Based Problem Solving in the Middle School: Design and Construction with Simple Machines. Journal of Pre-College Engineering Education Research, 3, 5. http://dx.doi.org/10.7771/2157-9288.1081

[11] Moore, T.J., Glancy, A.W., Rank, K.M., Kersten, J.A., Smith, K.A. and Stohlmann, M.S. (2014) A Framework for Quality K-12 Engineering Education: Research and Development. Journal of Pre-College Engineering Education Research, 4, 1-13. http://dx.doi.org/10.7771/2157-9288.1069

[12] Rogers, M.P., Abell, S. and Lannin, J. (2007) Effective Professional Development in Science and Mathematics Education: Teachers’ and Facilitators’ Views. International Journal of Science \& Mathematics Education, 5, 507-532. http://dx.doi.org/10.1007/s10763-006-9053-8

[13] Narode, R.B. (2011) "Math in a Can”: Teaching Mathematics and Engineering Design. Journal of Pre-College Engineering Education Research, 1, 14-18.

[14] Johnson, C.C. and Saylor, L.L. (2014) The Role of Reflection in Elementary Mathematics and Science Teachers' Training and Development: A Meta-Synthesis. School Science and Mathematics, 114, 30-39. http://dx.doi.org/10.1111/ssm.12049

[15] Stiles, K.E., Loucks-Horsley, S., Mundry, S. and Hewson, P.W. Eds. (2009) Designing Professional Development for Teachers of Science and Mathematics. Corwin Press, Thousand Oaks.

[16] Klein, S.S. (2009) Effective STEM Professional Development: A Biomedical Engineering RET Site Project. International Journal of Engineering Education, 25, 523-533.

[17] Nugent, G., Kunz, G., Rilett, L. and Jones, E. (2010) Extending Engineering Education to K-12. Technology Teacher, 69, 14-19.

[18] Carson, E. and Chiu, J. (2011) “E” Is for Innovation-How Does Solving Authentic Engineering Problems Impact Students' Comprehension Skills and Application Skills in Mathematics and Science? In: Koehler, M. and Mishra, P., Eds., Proceedings of Society for Information Technology \& Teacher Education International Conference, Chesapeake.

[19] Katehi, L. and Ross, M. (2007) Technology and Culture: Exploring the Creative Instinct through Cultural Interpretations. Journal of Engineering Education, 96, 89-90. http://dx.doi.org/10.1002/j.2168-9830.2007.tb00919.x

[20] Timperley, H., Wilson, A., Barrer, H. and Fung, I. (2008) Teacher Professional Learning and Development. International Academy of Education Working Paper, International Academy of Education, Educational Practices Series 18, London.

[21] Berland, L.K. (2013) Designing for STEM Integration. Journal of Pre-College Engineering Education Research, 3, 3. http://dx.doi.org/10.7771/2157-9288.1078

[22] AICTE (2011-12) All India Council for Technical Education Approval Process Handbook.

[23] Subbarao, E.C. (2013) India’s Higher Engineering Education: Opportunities and Tough Choices. Current Science, 104, 55-66.

[24] Sharma, N. (2014) Expansion of Engineering Education in India: Issues, Challenges and Achievable Suggestions. (C)Youth Education and Research Trust (YERT), Journal of Academia and Industrial Research, 3, 118-122. http://jairjp.com

[25] Gupta, D.P. and Dewanga, A. (2012) Challenges before Engineering Education in India. Researchers World: Journal of Arts, Science and Commerce, 3. www.researchersworld.com

[26] Mashelkar, R.A. (2011) Reinventing India. Sahyadri Prakasan, Pune.

[27] The Times of India Newspaper (2014) Boost for Engineers: India Now Part of Washington Accord. 
[28] Tilli, S. and Trevelyan, J.P. (2008) Longitudinal Study of Australian Engineering Graduates: Preliminary Results. The American Society for Engineering Education Annual Conference, Pittsburgh, 20-22 June 2008.

[29] Tenopir, C. and King, D.W. (2004) Communication Patterns of Engineers. Wiley \& Sons Inc., Hoboken.

[30] Bauer, C. and Figl, K. (2008) “Active Listening” in Written Online Communication-A Case Study in a Course on "Soft Skills for Computer Scientists". Paper Presented at the 38th ASEE/IEEE Frontiers in Education Conference, Saratoga.

[31] Trevelyan, J. (2010) Reconstructing Engineering from Practice. Engineering Studies, 2, 175-195. http://dx.doi.org/10.1080/19378629.2010.520135

[32] Thomas, E. (2005) Globalization, Cultural Diversity and Teacher in Cullingford \& Huddersfield. In: Cullingford, C. and Gunn, S., Eds., Globalization Education and Culture Shock, Ashgate Publishing Ltd., Surrey, 124-138.

[33] US National Academy of Engineering (2004) The Engineer of 2020: Visions of Engineering in the New Century. Washington DC.

[34] UK Royal Academy of Engineering (2007) Educating Engineers for the 21st Century, June 2007.

[35] Lohmann, J.R., Rollins Jr., H.A. and Hoey, J. (2006) Defining, Developing and Assessing Global Competence in Engineers. European Journal of Engineering Education, 31, 119-131. http://dx.doi.org/10.1080/03043790500429906

[36] Laker, D.R. and Powell, J.L. (2011) The Differences between Hard and Soft Skills and Their Relative Impact on Training Transfer. Human Resource Development Quarterly, 22, 111-122. http://dx.doi.org/10.1002/hrdq.20063

[37] Sharma, G. and Sharma, P. (2010) Importance of Soft Skills Development in 21st Century Curriculum. International Journal of Education \& Allied Sciences, 2, 39-44.

[38] Farr, J.V. and Brazil, D.M. (2009) Leadership Skills Development for Engineers. Engineering Management Journal, 21, 3-8. http://dx.doi.org/10.1080/10429247.2009.11431792

[39] Nair, C., Patil, A. and Mertova, P. (2009) Re-Engineering Graduate Skills-A Case Study. European Journal of Engineering Education, 34, 131-139. http://dx.doi.org/10.1080/03043790902829281

[40] Fuchs, W. (2006) A Way to the International Comparability of Engineering Education. IDEAS, 13, 16-21.

[41] Martin, R., Maytham, B., Case, J. and Faser, D. (2005) Engineering Graduates’ Perception of How Well They Were Prepared for Work in Industry. European Journal of Engineering Education, 30, 167-180. http://dx.doi.org/10.1080/03043790500087571

[42] Birch, J. (2007) The Feani Position on European Support for Innovation. IDEAS, 14, 26-31.

[43] Zaharim, A., Omar, M.Z., Yussof, Y.M., Muhamad, N., Mohamed, A. and Mustapha, R. (2010) Practical Framework of Employability Skills for Engineering Graduate in Malaysia. IEEE EDUCON 2010 Conference, Education Engineering 2010, the Future of Global Learning Engineering Education, Madrid, 14-16 April 2010, 921-927. http://dx.doi.org/10.1109/educon.2010.5492478

[44] ABET (2008) Criteria for Accrediting Engineering Programs 2008-2009. http://www.abet.org/

[45] Washington Accord (2012) International Engineering Alliance. www.ieagreements.org/Washington-Accord/

[46] National Accreditation Board (NAB) India (2010) Ministry of Human Resource Development, Government of India, India. www.nbaind.org/views/Home.aspx

\section{Scientific Research Publishing}

\section{Submit or recommend next manuscript to SCIRP and we will provide best service for you:}

Accepting pre-submission inquiries through Email, Facebook, Linkedin, Twitter, etc A wide selection of journals (inclusive of 9 subjects, more than 200 journals)

Providing a 24-hour high-quality service

User-friendly online submission system

Fair and swift peer-review system

Efficient typesetting and proofreading procedure

Display of the result of downloads and visits, as well as the number of cited articles

Maximum dissemination of your research work

Submit your manuscript at: http://papersubmission.scirp.org/ 